\title{
KONTRIBUSI LUKISAN BELUDRU TERHADAP PARIWISATA DI BUKITTINGGI
}

\author{
Rica Rian ${ }^{1 *}$, Suryanti $^{2 *}$, Rajudin $^{3^{*}}$ \\ Program Studi S1 Seni Murni Program Pendidikan Sarjana \\ Institut Seni Indonesia Padangpanjang \\ Jl. Bahder Johan, Guguak Malintang, Padangpanjang, Kota Padangpanjang, Kode Pos 27126 \\ Sumatera Barat. Indonesia \\ Email: ricarian341@gmail.com, yantisur688@gmail.com, sirajudinsiraj@gmail.com
}

\begin{abstract}
Abstrak
Penelitian ini mengungkap keberadaan seni lukis beludru di Bukittinggi. Penelitian ini untuk mengetahui potensi seni lukis beludru dan kontribusinya terhadap pariwisata di Bukittinggi. Penelitian tentang seni lukis beludru ditinjau dari potensi ke depannya kurang menjamin keberadaannya, mengingat makin lama makin sedikit regenerasi yang mau melestarikan melukis beludru, di samping itu keberadaan kios tempat seniman memajang karyanya semakin tersingkir. Kontribusi karya lukis beludru sangat besar pengaruhnya terhadap pariwisata di Bukittinggi mengingat animo wisatawan yang membeli karya mereka sebagai souvenir dari kunjungannya ke Bukittinggi. Metode yang dipakai dalam penelitian ini merujuk pada metodologi penelitian kualitatif, yaitu penelitian yang dimaksudkan untuk memahami keberadaan karya lukis beludru dan kontribusinya terhadap pariwisata di Bukittinggi dan kemudian dideskripsikan sesuai dengan konteks yang alamiah dan ilmiah. Dalam penelitian kualitatif metode yang biasa digunakan dalam mengumpulkan data adalah pengamatan, wawancara dan pemanfaatan dokumen di lapangan. Kemudian untuk laporan penelitian, data-data yang terhimpun disajikan berdasarkan kutipan data berupa kata/kalimat maupun data berupa naskah wawancara, catatan lapangan, foto, video, dokumen pribadi ataupun dokumen resmi lainnya.
\end{abstract}

Kata Kunci: lukisan beludru, kontribusi, wisata Bukittinggi.

\begin{abstract}
This research reveals the existence of velvet painting in Bukittinggi. In addition, this research wants to know the potential of velvet painting and its contribution to tourism in Bukittinggi. Research on velvet painting is reviewed from the potential for the future less guarantee of its existence, considering the longer the regeneration that will preserve velvet painting, in addition to the existence of stalls where the artist displays his work is increasingly knocked out. The contribution of velvet painting is very much an influence on tourism in Bukittinggi considering the interest of tourists who buy their work as a piece or a hand from his visit to Bukittinggi. The method used in this study refers to the qualitative research methodology, which is research that is intended to understand the existence of velvet painting and its contribution to tourism in Bukittinggi and then described in accordance with the natural and scientific context. In qualitative research methods commonly used in collecting data are observation, interview and utilization of documents in the field. Then for research reports, the data collected is presented based on excerpts of data in the form of words/ sentences or data in the form of interview scripts, field notes, photos, videos, personal documents or other official documents.
\end{abstract}

Keywords: velvet painting, contribution, Bukittinggi tourism.

\section{PENDAHULUAN}

Sumatera Barat dianugerahi alam yang indah dan eksotik yang membentang sepanjang batas wilayahnya seperti: Ngarai Sianok, Lembah Arau, Puncak Lawang, Tabek Patah, panorama Danau Maninjau, Danau Singkarak, Danau Kembar, Kebun Teh, Wisata Pantai dan lain-lain. Keindahan alam di Sumatera Barat tersebut menjadi inspirasi bagi seniman lukis untuk dituangkan ke dalam karya seni lukis, ada yang digarap dengan realis, naturalis, abstrak, naif, maupun dekoratif. Karya alam Minangkabau yang digarap seniman rata-rata menggunakan gaya naturalis pada media kanvas, di samping itu ada juga seniman yang menggarap lukisannya masih naturalis tetapi menggunakan bahan dari kain beludru.

Lukisan beludru merupakan salah satu karya seni rupa dua dimensi dengan media dari kain beludru berwarna hitam. Lukisan Beludru banyak dijumpai di Kota Bukittinggi tepatnya di daerah wisata Ngarai Sianok, di daerah wisata tersebut banyak dijumpai seniman yang melukis di studio yang memajang banyak hasil karyanya. Rata-rata seniman beludru memiliki 
latarbelakang non-akademis dalam bidang seni rupa lebih tepat disebut seniman otodidak.

Seniman lukis beludru menggarap karyanya di studionya hanya mengandalkan kekuatan imajinasi dari apa yang sudah dijumpai baik langsung maupun lewat foto, video, majalah dan lain-lain.Lukisan beludru mempunyai karakter tersendiri dalam segi pengambilan tema, setiap karya lukis yang dihasilkan selalu terdapat objek rumah gadang yang menjadi titik sentral, selain itu juga terdapat beberapa objek seperti: kincir, kolam, Jam Gadang, sugai, air terjun, gunung, pohon kelapa dan lain-lain. Pengerjaan melukis di kain beludru tidak menggunakan spandram, kegunaan spandram jika lukisan tersebut sudah selesai dikerjakan, alat yang digunakan untuk melukis menggunakan pisau palet bukan kuas, hal tersebut yang membedakan melukis beludru dengan di kanvas dan itulah salah satu daya tarik lukisan beludru bagi wisatawan yang berkunjung ke Bukittinggi.

Banyaknya seniman lukis beludru yang berkarya di tempat-tempat wisata tentu berdampak kepada pariwisata melalui karya lukis yang dibeli wisatawan baik lokal, nasional, maupun internasional sebagai oleh-oleh atau buah tangan dari kunjuangannya ke kota Bukittinggi. Karya lukis beludru hanya terdapat dan dibuat oleh seniman lukis di Bukittinggi dan sudah menjadi sebuah identitas bagi keberadaan seni lukis di Sumatera Barat dan berdampak bagus bagi sektor pariwisata karena objek yang dihadirkan mengangkat tentang panorama alam di Sumatera Barat

Keberadaan karya lukis beludru di Bukittinggi sangat menarik untuk diteliti dari segi potensi karya lukis beludru kedepannya di samping itu penelitian ini juga akan menelusuri pengaruh karya lukis beludru terhadap pariwisata di Bukittinggi.Penelitian ini menggunakan metode kualitatif serta didukung oleh beberapa teori sebagai penguat dalam penelitian.

\section{KAJIAN TEORI}

Salah satu unsur dalam penelitian yang memiliki peran sangat besar dalam pelaksanaan penelitian adalah teori, karena teori merupakan sebagai suatu sumber pemecahan dan pembedah dalam suatu permasalahan penelitian. Maka dalam penelitian ini landasan teori sebagai referensi ilmiah sangat diperlukan untuk memperkuat penelitian dalam menjawab rumusan masalah agar tidak terjadi pengambangan bahasan penelitian.

Ditambahkan Backer, tujuan seniman mendistribusikan karya: (1) permintaan efektif dihasilkan oleh orangorang yang mau mengeluarkan uang untuk seni. (2) apa
Gorga : Jurnal Seni Rupa

Volume 10 Nomor 01 Januari-Juni 2021

p-ISSN: 2301-5942 | e-ISSN: 2580-2380

yang mereka inginkan adalah apa yang telah mereka pelajari untuk dimintai dan diinginkan, dan ini adalah hasil pendidikan dan pengalaman. (3) harga bervariasi dengan permintaan dan kuantitas. (4) karya yang ditangani sistem adalah yang dapat didistribusikan sistem secara cukup efektif untuk tetap beroperasi. (5) cukup banyak seniman akan menghasilkan karya yang dapat didistribusikan secara efektif sehingga ini dapat terus beroperasi. (6) seniman yang pekerjaannya tidak dapat atau tidak akan ditangani sistem distribusi menemukan alat distribusi lain; sebagai alternatif, pekerjaan mereka mendapatkan distribusi minimal atau sama sekali.

\section{METODE PENELITIAN}

\section{Bentuk Penelitian}

Penelitian seni lukis beludru Bukittinggi ini berbentuk metode kualitatif yang berlawanan dengan penelitian kuantitatif. Menurut Bogdan dan Taylor (dalam Moleong, 1996: 4) bahwa pendekatan kualitatif adalah prosedur penelitian yang menghasilkan deskriptif, berupa kata-kata tertulis atau lisan dari orang-orang dan prilaku yang dapat diamati, pendekatan ini diarahkan pada latar dan individu tersebut secara holistik atau utuh.

Penelitian ini menggunakan dua jenis data yaitu data primer dan datasekunder. Kedua data ini saling berhubungan dalam pengolahan hasil penelitian. Data primer adalah data yang didapat langsung dari tangan pertama, sedangkan data sekunder adalah data yang dikutip atau dari sumber lain (Moleong, 1998:74). Data primer didapat dari pelaku yang terlibat langsung dengan seni lukis beludru di Bukittinggi. Data sekunder didapat dari koran, buku maupun tulisan yang berkaitan dengan seni lukis beludru Bukittinggi.

\section{Teknik Pengambilan atau Pengumpulan Data 1). Observasi}

Orang seringkali mengartikan observasi sebagai suatu aktiva yang sempit, yakni memperhatikan sesuatu dengan menggunakan makna (Arikunto, 2006: 156). Di dalam pengertian psikologi, observasi atau yangdisebut pula dengan pengamatan, meliputi kegiatan pemuatan perhatian terhadap suatu objek dengan menggunakan seluruh alat indra, jadi, mengobservasi dapat dilakukan melalui penglihatan, penciuman, pendengaran, peraba, dan pengecap.selain itu, tujuan dari observasi ini agar dapat langsung mengklasifikasikan data yang didapat serta guna mendapatkan sudut pandang tersendiri dalam meneliti seni lukis beludru Bukittinggi. 


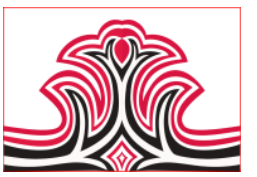

2). Wawancara

Wawancara adalah suatu teknik pengumpulan data untuk mendapatkan informasi yang digali dari sumber melalui percakapan tanya jawab. Menurut lexi J. Moleong (1988: 135) mengungkapkan bahwa wawancara adalah percakapan dengan maksud tertentu yang dilakukan oleh dua pihak yaitu pewawancara (interviewer) yang mengajukan pertanyaan, dan yang diwawacarai (interviewee) yang memberikan jawaban atas pertanyaan.

Wawancara dalam penelitian ini dilakukan dengan terjun langsung kelapangan, dan penulis mewawancari empat orang seniman lukis beludru yang telah cukup lama menggeluti seni lukis beludru dimulai dari dirintis sampai sekarang di Panorama Ngarai sianok yaitu Adji Agam, Iskandar dan Juneidi, sedangkan di Janjang Ampek Puluah hanya mewawancarai Herianto satusatunya pelukis beludru yang masih bertahan sampai sekarang.

\section{3). Studi Pustaka}

Studi pustaka adalah salah satu teknik pengumpulan data yang dilakukan dengan mengutip buku,koran maupun majalah yang berhubungan langsung dengan metode penelitian yang sedang dilakukan. Kepustakaanjuga merupakan daftar referensi dari semua jenis referensi seperti buku, jurnal papers, artikel, disertasi, tesis, skripsi, hand outs, laboratory manuals, dan karya ilmiah lainnya yang dikutip di dalam penulisan proposal yang berhubungan dengan seni lukis beludru Bukittinggi. Semua referensi yang tertulis dalam kajian pustaka harus dirujuk di dalam skripsi. Tinjauan pustaka juga bisa dikatakan sebagai kegiatan yang meliputi mencari, membaca, dan menelaah laporan-laporan penelitian dan bahan pustaka yang memuat teori-teori yang relevan dengan penelitian yang akan dilakukan.

\section{4). Analisa Data}

Dalam penelitian ini, analisis data dilakukan pada datadata yang telah dikumpulkan baik dari hasil tinjauan pustaka, obsevasi, wawancara dan dokumentasi yang terkait dengan seni lukis beludru di Bukittinggi. Ada dua cara yang dilakukan dalam menganalisis data yang pertama adalah membuat kategori terhadap data yang dikumpulkan dan memilih data yang terbaik. Kedua mengklarifikasikan data sesuai dengan rumusan masalah yang akan dijawab.

Data yang telah dikumpulkan tentang seni lukis beludru Bukittinggi diklasifikasikan atau dikelompokan maka data yang ada sesuai dengan rumusan masalah penelitian. Setelah dikelompokan maka data yang ada
Gorga : Jurnal Seni Rupa

Volume 10 Nomor 01 Januari-Juni 2021

p-ISSN: 2301-5942 | e-ISSN: 2580-2380

kembali ditinjau dan disaring, dikaji dengan teori sehingga mendapat suatu kesimpulan atas jawaban dari masalah.

\section{5). Populasi}

Populasi adalah seluruh data yang menjadi perhatian peneliti dalam suatu ruang lingkup dan waktu yang ditentukan (Sukardi, 2007: 53) Populasi dalam penelitian ini diambil dari keseluruhan objek yang ada pada lukisan beludru Bukittinggi yang akan diteliti. Selain itu pengambilan Sampel dalam penelitian ini dimulai dari tempat yang akan diteliti yaitu Panorama Ngarai Sianok dan Janjang Ampek Puluah, serta empat orang seniman lukis beludru yang masih mempertahankan profesinya sebagai pelukis, yaitu Adji Agam, Iskandar, Herianto dan Junaedi karena mereka yang masih bertahan dari awal dirintisnya seni lukis beludru sampai sekarang.

\section{HASIL DAN PEMBAHASAN}

1.Hasil

1). Lukisan Pemandangan Alam Minangkabau

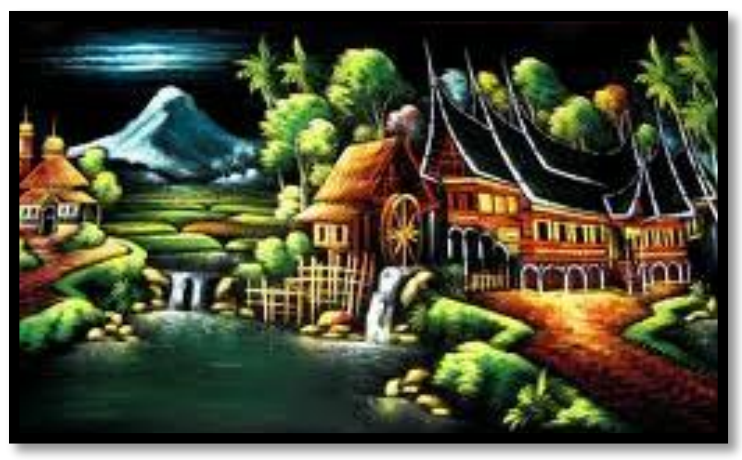

Gambar 1. Lukis Beludru dengan Pemandangan Alam Minangkabau (Rica, 2020)

\section{2). Foto Kegiatan Tahun Baru di Kota Bukittinggi}

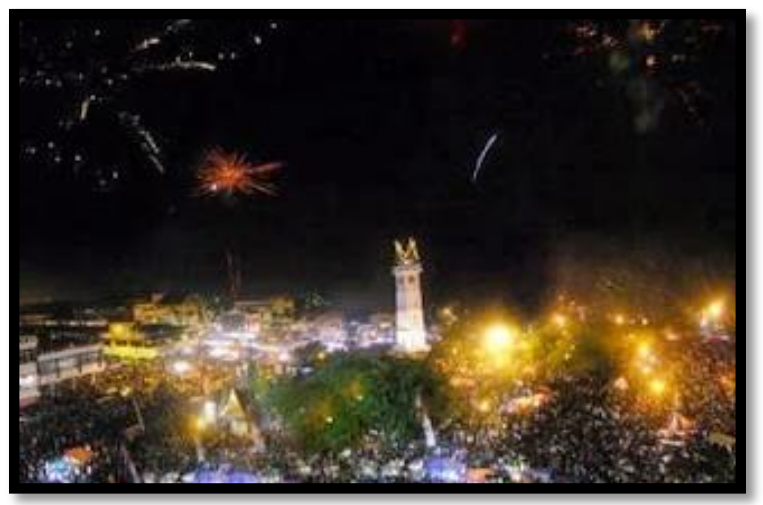

Gambar 2. Tahun Baru di Bukittinggi (Rica, 2020) 


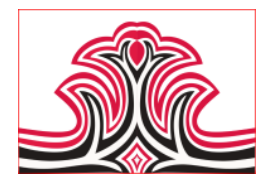

3). Lukisan Beludru yang Dijajarkan Dipanorama Ngarai Sianok

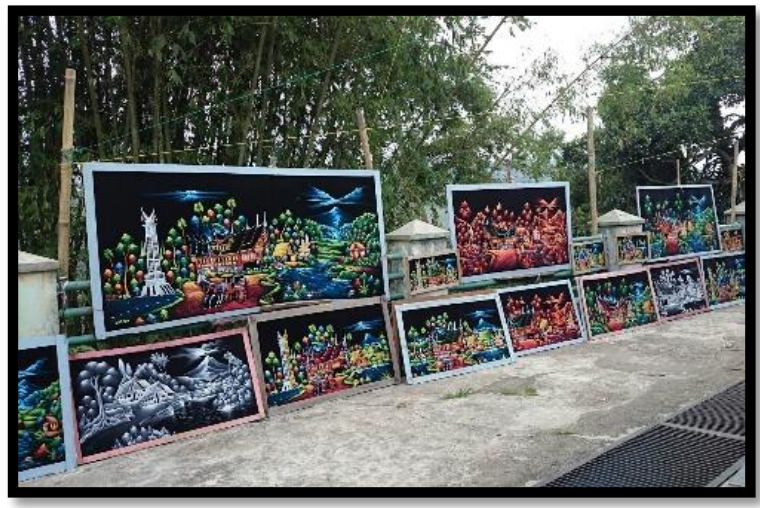

Gambar 3. Lukisan Beludru yang Dijajarkan Dipanorama Ngarai Sianok (Rica, 2020)

\section{4). Jam Gadang Bukittinggi}

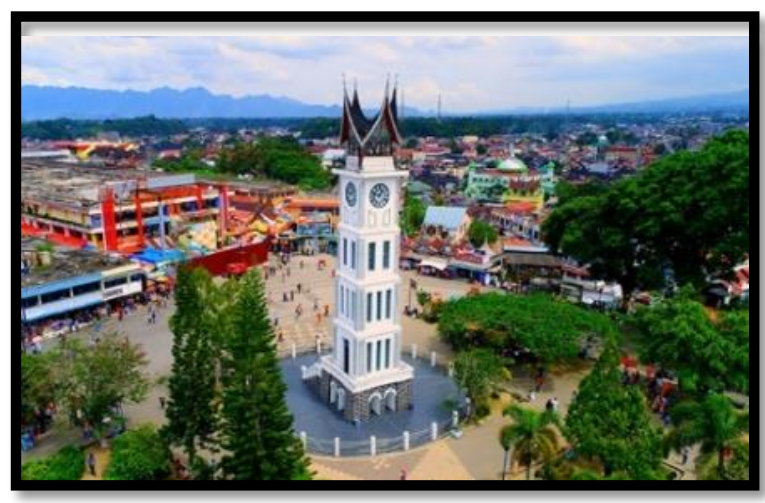

Gambar 4. Foto Jam Gadang (Rica, 2020)

\section{5). Kios Pemasaran Karya}

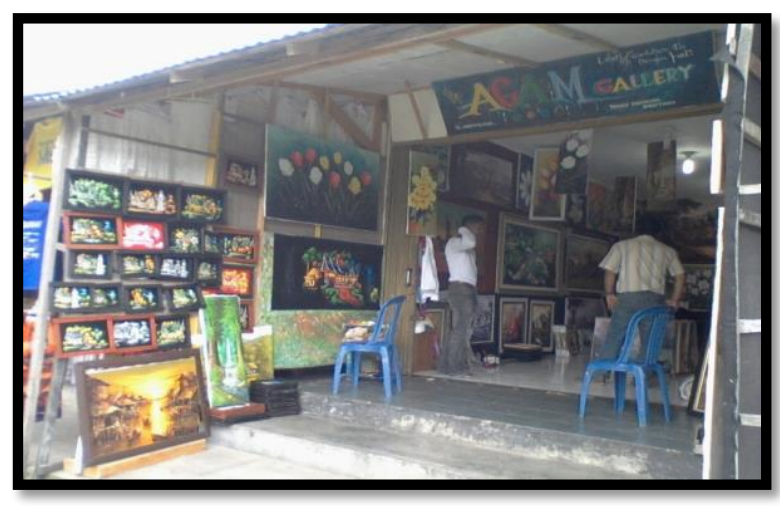

Gambar 5. Kios yang Dijadikan Tempat Pemasaran Karya Beludru di Panorama Ngarai Sianok (Rica, 2020)

\section{Pembahasan}

\section{1). Objek Karya Lukis Beludru Bukittinggi}

Pandangan masyarakat Minangkabau terhadap falsafah "Alam Takambang Jadi Guru" menjadikan orang Minangkabau belajar dari alam dan lingkungannya, demikian juga halnya seniman lukis yang menjadikan falsafah Alam Takambang Jadi Guru sebagai sumber inspirasinya dalam berkarya seni. Ketertarikan seniman
Gorga : Jurnal Seni Rupa

Volume 10 Nomor 01 Januari-Juni 2021

p-ISSN: 2301-5942 | e-ISSN: 2580-2380

lukis beludru mengangkat alam Sumatera Barat ke dalam karyanya didasari dari eksotis alam Minagkabau yang menarik minat wisatawan sebagai bingkisan atau buah tangan atas kunjunagnnya ke Bukittinggi. Dari berbagai macam ide tentang keidentetikan alam Sumatera Barat yang dituangkan ke karya seperti:

\section{(1). Rumah Gadang}

Dijadikannya rumah gadang sebagai ide penciptaan karya didasari oleh bangunannya yang megah, unik, karena objek rumah gadang sangat banyak yang bisa diekspos dan dijadikan ide seperti: kemegahan bentuknya, bentuk bangunan yang biasa-biasa saja, rumah gadang yang sedang dipugar, rumah gadang yang sudah tua (terabaikan). Selain rumah gadang terdapat juga objek Surau (tempat ibadah selain masjid). Seniman lukis beludru merepresentasikan bentuk sebuah rumah gadang, surau, kincir serta alam Minangkabau bukan berbicara persoalan bentuk melainkan manifestasi tentang perilaku manusia yang diangkat ke dalam karya seni lukis. Bentuk merupakan sesuatu yang diamati sesuatu yang memiliki makna, dan sesuatu yang berfungsi secara struktural pada objek-objek yang menjadi rangsang cipta dalam melukis. Berbagai karakteristik bentuk yang diciptakan seniman lukis beludru pada karyanya memiliki suatu rangam sumber yang luas, beberapa diantaranya langsung digambar dari alam atau dunia buatan manusia. Pada karya lukis beludru ada bentuk representasi rumah gadang, surau, kincir, pedati serta suasana alam Minangkabau yang damai, tentram dan kondisi alam Minangkabau yang asri.

\section{(2). Surau}

Dijadikan objek surau dalam karya lukis beludru didasari oleh fungsi surau dahulunya berfungsi sebagai tempat beribadah atau shalat tetapi sejak dari dulu sudah menjadi tempat/pusat kegiatan masyarakat selain tempat sholat juga sebagai tempat untuk mengaji, penulisan dan penyalinan kitap, diskusi keagamaan atau musyawarah, belajar adat, tempat berlatih ilmu beladiri. Surau bagi masyarakat Minangkabau tidak hanya sebagai tempat ibadah, namun surau dahulunya menjadi tempat tinggal bagi anak laki-laki yang mulai beranjak remaja. Di surau pula anak laki-laki yang mulai menginjak masa remaja lebih banyak menghabiskan waktunya setiap hari. Di surau mereka belajar mengaji Al-Quran dan juga tafsirnya, ilmu hadis, Aqidah, Ibadah, Muamalah, dan materi keislaman lainnya. Di surau mereka juga belajar tentang petatah-petitih adat Minangkabau, beladiri, randai, dan berbagai kesenian serta adat budaya Minangkabau lainnya. Di surau jugalah mereka ditempa dan dipersiapkan untuk menjadi pribadi yang 
siap menanggung beban dan amanah dikemudian harinya.

Pemuda Minangkabau sejak kecil telah dituntut untuk mencari ilmu. Filosofi Minangkabau yang mengatakan bahwa "alam takambang jadi guru", merupakan suatu adagium yang mengajak masyarakat Minangkabau untuk selalu menuntut ilmu. Pada masa kedatangan Islam, pemuda-pemuda Minangkabau selain dituntut untuk mempelajari adat-istiadat juga ditekankan untuk mempelajari ilmu agama.Hal ini mendorong setiap kaum keluarga, untuk mendirikan surau sebagai lembaga pendidikan para pemuda kampung.

\section{(3). Alam}

Sumatera Barat memiliki alam yang indah yang didukung oleh perbukitan dan gunung, danau, sawah, sungai yang asri yang dijadikan objek oleh seniman dalam berkarya. Di Sumatera Barat terdapat tempattempat wisata yang menarik seperti: Ngarai Sianok, Lembah Harau, Jam Gadang, Pantai Malin Kundang, Danau Singkarak, Danau Maninjau, Danau di Atas dan di Bawah, Air Terjun Lembah Anai, kincir, pedati, dan lain-lain. Dari dahulunya alam Minangkabau sudah banyak dijadikan objek bagi seniman baik lokal maupun seniman luar seperti Wakidi pada masa Moii Indie.

Karya seniman beludru di Bukittinggi ini merupakan karya seni fantasi. Seni fantasi memberi peluang bagi seniman untuk keluar dari aturan-aturan seni yang telah diwariskan, termasuk aturan atau pedoman dalam seni klasik yang telah mapan, untuk menciptakan bentukbentuk atau ide-ide sesuai dengan yang diimpikan. Kemungkinan lahirnya bentuk-bentuk fantasi itu bisa berawal dari kehendak sang seniman melakukan eksperimen, pengaruh seniman lain, keinginan untuk mengembangkan atau memberontak pakem-pakem seni yang telah mapan, ataupun temuan yang bersifat sekunder karena pengaruh penggunaan media atau teknik baru. Bentuk fantasi atau temuan atau pengembangan itu kemudian menjadi renungan seniman bersangkutan sehingga karya-karya yang diciptakan cenderung tergolong gaya fantasi. Menurut Feldman (1967: 204-207) penciptaan fantasi merupakan refleksi persepsi seniman atas perannya sebagai seorang yang menuruti pedoman termasuk dalam kenyataan, atau seseorang yang memiliki misi mengubah aturan. Baik secara sengaja menciptakan bentuk-bentuk baru yang ganjil atau logis dan dapat dipercaya ataupun membiarkan bentuk-bentuk fantasi menutut keinginannya, sebagai instrumen yang bekerja sama dengan berbagai dengan berbagai proses penciptaan di dunia. Menurutnya, karena seni fantasi menimbulkan kedua proses mental yakni logis dan irasional, maka seni tersebut tidak menyajikan aturan umum kwalitas visual. Karya-karya fantastis mungkin akurat secara objektif atau distorsi secara subjektif. Oleh karena itu, seni fantasi bisa saja terkait dengan ilmu pengetahuan atau dunia motologi.

\section{2). Pasar Karya Lukis Beludru Bukittinggi}

Menjual karya seni adalah pemecahan masalah". Ini tidak hanya menyediakan pendapatan, ini membuktikan pada diri sendiri dan orang lain bahwa seni adalah pekerjaan, dan bukan kegemaran belaka (McCall 1978: 307). Para seniman, yang telah membuat karya, perlu mendistribusikan karyanya untuk menemukan mekanisme yang akan menimbulkan apresiasi orang-orang untuk mengaksesnya dan secara bersamaan akan mengganti investasi akan waktu, uang, dan material di dalam karya sehingga lebih banyak waktu, material, dan aktifitas kerjasama yang akan tersedia untuk membuat lebih banyak karya. Para seniman dapat bekerja tanpa distribusi. Seniman tidak pernah merealisasikan uang dari karya mereka dan tidak dapat menyokong karya selanjutnya yang merupakan kelanjutan dari apa yang telah mereka lakukan. Seniman tetap berorientasi pada dunia seni untuk memerlukan sistem distribusi-nya untuk membawa karya yang sudah selesai pada para audiens, jika tidak untuk sokongan ekonomi. Seniman tidak hanya bekerja guna memberi kesempatan untuk mengenal talenta dan inovasinya serta untuk memasukkannya ke bidang pekerjaan maupun untuk mendapatkan keuntungan komisi, tetapi juga menyebarkan pengetahuan baru guna memperluas penggemar termasuk publik atau audiens kepada seni yang telah meresap dalam kehidupan masyarakat modern.

Berbagai gagasan atau pesan pribadi yang disampaikan melaui karya-karyanya tentulah seniman ingin mengkomunikasikan pada orang lain, dengan harapan agar orang yang dan mengoleksi karyanya turut merasakan dan memahami gagasan-gagasan atau pesan yang disampaikan, ketika pesan atau nilai itu sampai pada orang lain yang mengamati dan bahkan mampu mempengaruhi perlaku orang tersebut, maka pada saat itu karya tersebut telah memerankan fungsinya meskipun gagasan awalnya bersifat pribadi. Seperti dijelaskan Sumardjo (2000: 4) walaupun gagasan seni bersifat pribadi namun orientasinya selalu untuk orang lain, bukan hanya untuk diri seniman itu sendiri atau hanya sebagai terapi pribadi. Bagaimanapun seniman sebagai makluk sosial akan mencipta, karena dan untuk masyarakatnya, entah itu memiliki nilai kegunaan praktis ataupun nilai yang bersifat esensi. Di lain sisi, 
Pasar sangat menentukan sekali bagi kelangsungan hidup seniman lukis beludru di Bukittinggi. Pasar memberikan nilai berupa imbalan kepada seniman, dan seniman sebaliknya memberikan hasil karyanya sebagai bukti atas kesepakatan seniman membutuhkan uang dan penikmat butuh karyanya. Seniman tetap berorientasi pada dunia seni untuk memerlukan sistem penjualan untuk membawa karya yang sudah selesai pada para audiens jika tidak untuk sokongan ekonomi. Terkait dengan mendistribusikan karya seni, Feldman (1967: 61-62) menyebutkan karya seni yang menarik itu apabila: (1) karya seni itu cenderung mempengaruhi perilaku kolektif orang banyak, (2) karya itu diciptakan untuk dilihat atau dipergunakan, khususnya dalam situasi-situasi umum, (3) karya seni itu mengekspresikan atau menjelaskan aspek-aspek tentang eksistensi sosial atau kolektif sebagai lawan dari bermacam-macam pengalaman personal maupun individual. Selanjutnya disebutkan, dalam tiga kasus tersebut, seorang individu menanggapi seni dengan kesadaran sebagai anggota dari suatu kelompok, yang dalam beberapa hal dikarekterisasikan atau didorong untuk melakukan sesuatu oleh karya seni yang disaksikan.

Penjelasan Feldman tersebut, karya-karya lukis beludru secara umum bisa diindentifikasi dari tema-tema tentang Minangkabau yang banyak diminati pengunjung seperti: Rumah Gadang, gunung, kincir, surau, sawah, dan lain-lain. Lukisan beludru yang dibuat sarat dengan nuansa Minangkabau. Karya lukis beludru yang dibuat yang bertemakan nuansa Minangkabau tentunya bermaksud turut menyampaikan keindahan serta keunikan Sumatera Barat kepada masyarakat dan wisatawan yang berkunjung ke Bukittinggi khususnya, dan semua tema itu dihadirkan untuk mempengaruhi perilaku kolektif orang yang melihat karya tersebut sehingga ada keinginan untuk melihat dan membelinya.

Kehadiran seniman lukis beludru di Bukittinggi yang konsisten berkarya dengan mengangkat nuansa alam Minangkabau dalam karyanya tentu menjadi tantangan tersendiri dalam bersaing dengan seni kontemporer yang sedang buming di kalangan seniman Sumatera Barat. Apresiasi yang setinggi-tingginya layak diberikan kepada seniman lukis beludru yang konsisten berkarya dengan selalu mengangkat alam Minangkabau dalam karyanya, banyak seniman yang terpengaruh dengan rayuan seni kontemporer yang sangat memberi keuntungan besar di pasar kolektor seni. Seniman lukis beludru yang yang konsisten berkarya dengan tema nuansa Minagkabau tidak kalah pamor jika dibandingkan dengan seniman yang menggunakan tema kontemporer. Karya lukis beludru memiliki pasar tersendiri salah satunya sebagai buah tangan bagi wisatawan yang berkunjung ke Sumatera Barat, perantau yang memajang karya beludru di rumahnya maupun ditempat usahanya seperti rumah makan yang menarik pelanggan dan menambah kekaguman akan alam Minangkabau yang eksotis. Selain itu instansi pemerintah banyak juga yang memajang karya lukis beludru, serta kurator seni pun banyak mengoleksi karya lukis beludru dengan nuansa Minangkabau.

Disimpulkan bahwa kehadiran seniman lukis beludru di Sumatera Barat dan Bukittinggi khususnya. Kalau seniman lukis beludru memilih ini sebagai pilihan untuk menyambung kehidupannya tentu memberikan peluang yang menjanjikan, dan juga membantu pelestarian budaya lewat karya-karya yang dihadirkan. Menyikapi pasar karya lukis beludru tergantung kepada wisatawan yang pengunjung Bukittinggi, wisatawan yang ramai berwisata kebukittinggi meliputi:

\section{(1). Libur Sekolah}

Musim liburan sekolah membuat kota Bukittinggi dipadati pengunjung itu terlihat dari kemacetan diberbagai ruas jalan kota. Wisatawan yang datang dari berbagai daerah di Sumatera Barat dan provinsi tetangga ini memadati berbagai objek wisata, terutama di kebun binatang, Jam gadang dan Ngarai sianok. Di musim liburan, pengunjung objek wisata mengalami peningkatan dari hari biasanya, di Ngarai sianok pada hari libur sekolah pengunjung biasanya datang secara berkelompok dengan memakai bus besar dan apabila salah satu dari pengunjung membeli maka yang lainnya akan ikut pula kata Iskandar salah satu seniman lukis beludru. Lukisan yang terjual pada liburan sekolah biasanya pengunjung akan membeli lukisan berukuran kecil sesuai dengan kantong anak sekolahan yaitu dengan harga 50.000 - 100.000 rupiah, lukisan dengan ukuran 25x30 cm ini akan mendapatkan bonus berupa tambahan pembuatan nama pembeli sendiri di sudut bawah lukisan, atau sesuai dengan permintaan sehingga dapat dijadikan sebagai kenang-kenangan dari tempat wisata Ngarai Sianok Bukittinggi. Selain itu, lukisan yang berukuran besarpun banyak yang laku dengan harga rata-rata 300 ribu.

\section{(2). Tahun Baru}

Kota Bukittinggi merupakan tempat tujuan utama perayaan malam tahun baru, baik yang berasal dari Kota Bukittinggi sendiri maupun dari kabupaten dan kota lainnya di Sumatera Barat serta provinsi lainnya. Bahkan, sejumlah wisatawan asing juga tak ingin melewatkan suasana kemeriahan malam tahun baru 
yang sering diadakan di kawasan Jam Gadang. Pada tahun baru tingkat penjualan lukisan beludru sama dengan hari libur sekolah mengalami peningkatan dari pada hari biasanya, karena mulai dari sore hari para pengunjung sudah berdatangan memenuhi tempattempat wisata Bukittinggi Jam Gadang sampai jam dua belas malam sebagai acara puncak tahun baru, termasuk Panorama Ngarai Sianok salah satu tempat lukisan beludru berada, dan biasanya pada hari itu penjualan lukisan beludru cukup baik dari hari biasanya kata Adji Agam salah satu pelukis beludru Ngarai sianok.

\section{(3). Lebaran Hari Raya}

Pada hari raya Idul Fitri Kota Bukittinggi berubah sesak. Wisatawan dari berbagai daerah akan pergi berwisata ke Bukittinggi untuk menyambut hari lebaran, berbeda dengan kota lain, kota Bukittinggi menjadi ramai jika lebaran datang, apalagi banyak perantau yang baru pulang dari tanah rantaunya. Lebaran hari raya merupakan hari yang sangat membahagiakan oleh umat Islam karena pada hari itu merupakan hari besar, karena telah melakukan puasa dan ibadah lain dengan pahala berlipat ganda selama satu bulan penuh. Selain itu, juga bisa berkumpul dengan keluarga yang dekat maupun yang jauh dari rantau, begitu juga dengan seniman lukis beludru pada hari raya penjualan lukisan beludru meningkat drastis. Pada hari biasa seniman lukis beludru hanya bekerja membuat lukisan sebanyak-banyaknya untuk persiapan hari raya atau lebaran, dalam setahun itu seniman membuat lukisan dari berbagai ukuran, kurang lebih lima sampai enam ribu buah dan lukisan yang telah dibuat akan terjual habis pada hari lebaran.

Ketiga waktu yang dipaparkan di atas akan menjadi masa panen bagi para pelukis beludru untuk mendapatkan keuntungan lebih, dari ketiga waktu tersebut, merupakan waktu yang diharapkan untuk dapat membayar tempat dalam setahun. selain itu, para seniman pelukis beludru juga dapat membayar semua kebutuhan hidup mulai dari biaya sekolah sampai biaya kehidupan sehari-hari. Tiga waktu ini yang menjadi harapan bagi para pelukis beludru sejak dimulainya krisis moneter sampai sekarang, belum lagi menghadapi aturan berdiam di rumah selama virus corona melanda.

\section{3). Pengaruh Lukisan Beludru Terhadap Pariwisata Bukittinggi}

Seni lukis dari kain beludru sangat diminati oleh masyarakat Bukittinggi maupun wisatawan yang datang dari luar daerah, karena selain lukisan yang lebih dominan dengan alam Minangkabau juga harga yang terjangkau oleh ekonomi masyarakat. Lukisan beludru di Bukittinggi mulai dikenal oleh masyarakat dan sangat diminati dengan dibuktikan banyaknya wisatawan yang membeli dan memajang di rumah. Perkembangannya juga mulai terlihat ketika banyak seniman yang membuat seni lukis beludru sebagai profesi pekerjaan di kota Bukittinggi.

Seni lukis beludru ada pada tahun 1985 yang dirintis oleh seorang seniman otodidak yaitu Anton dari Palembang, setelah pulang merantau dari pulau Jawa tepatnya di Jawa Barat, Anton mendapat sebuah ide untuk membuat lukisan dengan media kain beludru di Bukittinggi yang terinspirasi dari seniman Bandung yang telah terlebih dahulu menemukan media kain ini dan pada ada awalnya Anton melukis hanya sendiri.

\section{4). Lukisan Beludru Dijajarkan Dipanorama Ngarai Sianok}

Anton pada mulanya mulai mencoba melukis di bawah Jam Gadang, lukisan beludru yang dibuat Anton banyak menarik perhatian masyarakat yang datang berwisata di sekitar Jam Gadang, karena warna yang sangat menonjol dengan warna cerah dan didukung oleh background kain beludru warna hitam yang tajam membuat masyarakat atau siapapun yang melihat pada awal-awalnya akan tertarik, kata Adji Agam salah satu pelukis beludru yang mengikuti Anton sebagai pelukis beludru. Selain itu, dibuktikan dengan banyaknya orang yang membeli dan memesan lukisan beludru. Seiring dengan berjalannya waktu pelukis beludru makin bertambah banyak dengan munculnya beberapa orang seniman lain di antaranya Edi, Romi, Zal, Man, Oyong, Irwan, Madi, Pin, Heri, hingga yang muda, para Seniman ini tertarik karena melihat lukisan beludru sangat diminati masyarakat, seperti Heri sebagai seniman otodidak lukisan potret wajah Jam Gadang mau berhenti sebagai pelukis potret pada tahun 1988 dan pindah menjadi pelukis beludru, karena lukisan beludru sangat menarik perhatiannya dari segi bahan dan trend pada masa itu.

\section{5). Jam Gadang Bukittinggi dan Kios Pemasaran}

Bukittinggi merupakan tempat pilihan utama bagi seniman lukis beludru untuk menunjang hasil dari penjualan lukisannya, karena selain lingkungannya yang sarat sejarah juga sebagai tempat wisata yang aman dan asri serta masyarakat dengan kebudayaan Minang yang unik seperti adat-istiadat sampai dengan masakan yang terkenal dan beragam, tata cara hidup dengan kebanyakan berjualan mulai dari pernak-pernik sampai kulinernya sehingga sangat mendukung dan 
juga berdampak terhadap seniman lukis beludru dalam menunjang penjualan lukisan.

Bukittinggi juga mempunyai banyak peninggalan sejarah selain Jam gadang sebagai tempat wisata, seperti Janjang ampek puluah dan lobang Jepang yang berada di Panorama Ngarai sianok, Panorama Ngarai Sianok dijadikan sebagai tempat lukisan beludru setelah dua tahun pembenahan Jam terjadi. Ada tiga orang pelukis beludru yang menetap di kios-kios Panorama tersebut, yaitu Adji Agam, Iskandar dan Edi, sedangkan di Janjang ampek puluah ada Heri yang mengatakan pengaruh seni lukis beludru terhadap pariwisata ada beberapa alasan yaitu: a). Adji Agam yang berada di Panorama Ngarai Sianok sering didatangi oleh pengunjung wisata panorama selain berkunjung ke Lobang Jepang juga untuk memesan lukisan beludrunya, b). Herianto yang berada di Janjang ampek puluah sering menjual lukisan beludru terhadap wisatawan luar negeri, seperti wisatawan dari Malaysia yang dibawa ke galeri lukisannya oleh agen wisata Bukittinggi sebagai salah satu bentuk wisata yang menarik di Bukittinggi, c). Lukisan beludru yang kebanyakan dengan tema Jam Gadang, Bendi, Ngarai Sianok dan peninggalan serta tempat wisata lainnya, menjadikan lukisan beludru sebagai oleh-oleh wisata sekaligus sebagai media promosi wisata Bukittinggi baik di dalam maupun luar negeri.

Pada tahun 1990 terjadi pembenahan wisata oleh pemerintah setempat khususnya tempat wisata Jam Gadang Bukittinggi, pada saat itu seniman lukis beludru masih beraktifitas di areal Jam Gadang dan belum mempunyai kios, hanya memajang beberapa lukisan di area terbuka seperti di sekitar pagar yang ada di Jam Gadang dan kalau telah selesai lukisan dibawa pulang ke rumah masing-masing. Pohon-pohon yang ada di sekitar area dikurangi dan taman serta pagar dibuat seperti gaya taman yang ada di Eropa. Akibat dari penertiban ini banyak para pelukis beludru pindah mencari tempat yang baru seperti di Ngrai Sianok dan menyewa kios itu terjadi pada tahun 1995. Dari tahun 1995 sampai tahun 1998 penjualan lukis beludru sangat meningkat dan pelukis beludru saat itu bisa dibilang sukses dan segala kebutuhan melukis maupun kehidupan dalam keluarga mereka melebihi dari cukup dan ada dari beberapa seniman sudah bisa membeli tanah maupun membangun rumah.

Bila berkunjung ke kota Bukittinggi, para wisatawan akan menjumpai beberapa tempat yang menjual karyakarya seni lukis kain beludru ini, demikianlah sampai sekarang, para pelukis-pelukis beludru ini masih tekun dalam mencari rupiah lewat karya-karyanya, dan berharap dapat berkembang dan semakin diapresiasi oleh masyarakat dan wisatawan khususnya. Jika mencermati perkembangan seni lukis beludru mengalami penurunan pada tahun 2020 ini, mengingat sektor pariwisata di Bukittinggi yang menurun akibat pandemi virus corona. Pengunjung yang datang ke Bukittinggi tidak sebanyak tahun 2019, namun penurunan tersebut sangat berdampak kepada eksistensi seniman lukis beludru yang kesulitan memasarkan karya-karyanya dan memilih berkarya melalui pesanan. Jika ditelusuri jauh ke belakang, lahirnya seni lukis beludru Bukittinggi tidak lepas dari beberapa kendala seperti:

\section{(1). Faktor Ekonomi}

Faktor ekonomi merupakan salah satu faktor adanya seni lukis beludru di Bukittinggi, Anton sebagai seniman pertama yang merintis mencoba membuat karya seni lukis beludru untuk mencari nafkah dalam memenuhi kebutuhan kehidupan sehari-harinya. Lahirnya suatu karya seni bisa di dorong oleh banyak motivasi. Ada yang lahir karena keinginan manusia akan hal yang indah-indah, ada yang karena kehendak manusia untuk berkomunikasi dengan sesamanya, dan ada pula yang didorong oleh desakan untuk memenuhi kebutuhan sehari-hari (Soedarso, 2006: 101).

\section{(2). Faktor adanya Peluang Usaha Baru}

Sebelum adanya seni lukis beludru lukisan yang ada pada waktu itu kebanyakan bahannya dari kanvas, sedangkan seni lukis beludru media yang digunakan yaitu kain beludru yang belum ada digunakan oleh pelukis Bukittinggi sebelumnya. Tema yang di angkat oleh seperti pemandangan alam Minang, Rumah Gadang, Surau dan lainnya yang mendukung dalam segi kreatifitasnya sebagai pelukis dalam mendapatkan ide baru. Kreatifitas adalah suatu kondisi, suatu sikap atau keadaan mental yang khusus sifatnya dan hampir tak mungkin dirumuskan. Kretifitas adalah kegiatan mental yang sangat individual yang merupakan manifestasi kebebasan manusia sebagai individu, manusia kreatif adalah mutlak. Kreatifitas menerjunkan seseorang kedalam keadaan yaitu di antara keadaan ada dan belum ada. Dengan demikian seseorang yang kreatif selalu dalam kondisi kacau, ricuh, kritis, gawat dan mencari-cari, mencoba-coba untuk menemukan sesuatu yang belum pernah ada dari tatanan budaya yang dipelajari (Sumardjo, 2009: 80). Kreatif merupakan ciri khas sifat manusia. Oleh karena itu, kreatifitas secara potensial ada dalam diri manusia tidak ada manusia yang tidak memiliki potensi ini, persoalannya adalah ada manusia yang mempunyai potensi besar dan ada yang cenderung kecil untuk menuju ke arah pembaharuan (Rohidi, 2000: 22). 


\section{(3). Faktor Unik dan Murah}

Kain beludru dengan harga murah tidak memerlukan modal besar dalam melukis, dan kainnya yang unik untuk sebuah media lukisan, karena kain beludru biasanya di negeri Minang dipakai sebagai pakaian Bundo Kanduang, dengan harga murah dan unik tentu akan menarik masyarakat yang ingin menikmati seni lukis ini untuk membeli dan memajangnya di rumah, Suatu proses sosial dan kebudayaan yang besar, tetapi yang terjadi dalam jangka waktu yang tidak terlalu lama disebut dengan inovasi atau inovation. Proses tersebut meliputi penemuan baru, jalannya unsur kebudayan baru yang tersebar kelain-lain bagian masyarakat, dan cara unsur-unsur kebudayaan baru tadi diterima, dipelajari dan akhirnya dipakai dalam masyarakat yang bersangkutan (Koentjaraningrat, 1965: 35).

Kesimpulan lahirnya faktor seni lukis beludru Bukittinggi setelah ditelusuri di lapangan memang lebih kepada faktor ekonomi dan adanya peluang, ketika melihat ada kesempatan tentu siapapun akan mengambil kesempatan itu, begitu juga dengan Anton seni lukis beludru sebelum dirintisnya memang belum ada sehingga akan menariknya untuk memulai dan merintisnya.

Kemunculan karya lukis beludru dibuat oleh seniman lukis yang berkarya di areal sekitar Jam Gadang, langsung melukis pemandangan alam Minang dengan rumah gadangnya, karena dengan alasan Bukittinggi sebagai kota wisata harus mempunyai daya tarik tersendiri selain dari peninggalan sejarahnya, salah satunya yaitu dengan lukisan beludru alam Minangnya. Pemandangan alam Minang yang dilukis Anton merupakan salah satu wujud jiwa dalam mengekspresikan diri terhadap lingkungan tempat tinggalnya, S. Sudjojono (dalam Sachari, 2002: 55) menyebutkan seorang seniman atau pelaku kesenian dalam mengekspresikan diri hakikatnya merupakan wujud jiwanya sendiri (jiwa ketok)..kesenian adalah jiwa. Apapun yang menjadikan objek lukisan atau karya seninya merupakan ekspresi dari jiwa. Karya seni yang mengagumkan adalah karya seni yang mengekspresikan jiwa yang besar. Pengaruh seni lukis beludru Bukittinggi terlihat dari beberapa hal yang telah dilihat di lapangan yaitu: a). Banyaknya agen wisata Bukittinggi yang membawa wisatawan yang datang berkunjung ke galeri seni lukis beludru untuk memperkenalkan lukisan beludru sebagai salah satu bentuk dari wisata yang harus dilihat pengunjung, b). Seni lukis beludru merupakan salah satu media promosi wisata Bukittinggi karena tema seni lukis beludru banyak berupa tempat wisata seperti Jam Gadang dan
Ngarai Sianok Bukittinggi, c). Seni lukis beludru Bukittinggi merupakan salah satu buah tangan pengunjung yang datang, dibuktikan dengan banyak pengunjung memesan lukisan dengan jumlah banyak, d). Seni lukis beludru di Sumatera Barat lebih identik dengan wisata Bukittinggi, walaupun sudah ada beberapa daerah yang mulai menjual seni lukis beludru seperti Solok, e). Seniman lukis beludru Bukittinggi sering pameran keluar negeri seperti Malaysia dan Singapura dengan membawa nama Bukittinggi sebagai asal tempat lukisan beludru didatangkan. Pengaruh seni lukis beludru Bukittinggi terhadap pariwisata Bukittinggi sangat banyak, dan tentu dari pengaruhnya ini akan berdampak positif terhadap wisatawan yang datang ke Bukittinggi sebagai salah satu tempat wisata yang ada di Sumatera Barat.

\section{KESIMPULAN DAN SARAN}

\section{Kesimpulan}

Pengaruh seni lukis beludru terhadap pariwisata di Bukittinggi sangat terasa dan berdampak positif terhadap pengunjung pariwisata yang datang ke Bukittinggi, salah satu dampaknya yaitu banyak wisatawan yang datang membeli lukisan beludru sebagai kenang-kenangan wisata dari Bukittinggi. Teknik yang dipakai untuk melukis beludru yaitu teknik basah dengan cara ditotol, semua pelukis beludru Bukittinggi memakai teknik ini karena cuma teknik ini yang cocok untuk bahan dengan kain beludru. Bahan yang digunakan terdiri dari kain beludru dan cat minyak, sedangkan untuk alat yang digunakan merupakan alat standar melukis biasa pada media kanvas.

\section{Saran}

Seni lukis beludru Bukittinggi bisa dijadikan salah satu daya tarik wisata kota Bukittinggi. Untuk itu, masyarakat sekitar dan pemerintah daerah lebih peduli dan memperhatikan keluhan yang dialami seniman lukis beludru seperti permintaan peminjaman modal dan fasilitas untuk berkarya seperti penempatan tempat untuk memasarkan karya agar seniman lukis beludru tetap eksis berkarya dengan nuansa Minangkabaunya. Keberadaan seniman lukis beludru di Bukittinggi sangat berpengaruh terhadap wisatawan yang berkunjung ke Sumatera Barat, dan memperkenalkan wisata yang dimiliki Sumatera Barat kepada masyarakat luas lewat karya cenderamata berupa karya lukis beludru yang dibelinya. Keberadaan seni lukis beludru di Sumatera Barat terdapat di kota Bukittinggi dan merupakan kebanggaan terdiri mengingat seni lukis beludru ada dan lahir di Bukittinggi, dan seharusnya seni ini dijaga dan dilestarikan. 


\section{DAFTAR RUJUKAN}

Arikunto, Suharsimi. (2006). Prosedur Penelitian; Suatu Pendekatan Praktik. Jakarta: PT RINEKA CIPTA.

Cattoretti, G., Becker, M. H., Key, G., Duchrow, M., Schlüuter, C., Galle, J., \& Gerdes, J. (1992). Monoclonal antibodies against recombinant parts of the Ki-67 antigen (MIB 1 and MIB 3) detect proliferating cells in microwaveprocessed formalin-fixed paraffin sections. The Journal of pathology, 168(4), 357-363.

Feldman, Burke, Edmund. (1967). Art As Image and Idea. New Jersey: Englewood Cliffs.

Koentjaraningrat. (1965). Pengantar Antrologi. Jakarta: Penerbit Universitas.

Moleong, Lexy, J. (1998). Metodologi Penelitian Kualitatif. Bandung: PT. Remaja Rosdakarya.

McCall. (1978). Art Worlds. California: University of California Press.

Rohidi, Tjep Tjep, Rohend. (2000). Kesenian dalam Pendekatan Kebudayaan. Bandung: STSI.

Rica, Rian. (2020). "Dokumentasi Karya Lukis Beludru”. Hasil Dokumentsi Pribadi: 2020, Bukittinggi.

Sachari, Agus. (2002). Estetika. Bandung: ITB.

Sukardi. (2007). Metodologi Penelitian Pendidikan. Yogyakarta: Bumi Aksara.

Sumardjo, Jakob. (2000). Filsafat Seni. Bandung: ITB.

Soedarso SP. (2006), Tinjauan Seni. Yogyakarta: Saku Daya Sana. 